\title{
$\mathrm{SF}_{6}$ ガス凝縮層を用いた JT-60NBI 用大容量
}

\section{クライオソープションポンプによる $\mathrm{He}$ 排気*}

\begin{tabular}{|c|c|c|c|}
\hline 柴沼 & 清**. 秋野 & 昇**. 大楽 & 正幸** · 蛭田 \\
\hline 飯田 & 一広**. 菊池 & 勝美** . 国枝 & 俊介**. 栗山 \\
\hline & 守**. 野本 & 弘樹**. 小原 & 祥裕**.大内 \\
\hline 4 & 豊** ·関 & 昌弘 ${ }^{* *}$. 田中 & 茂**. 寺門 \\
\hline
\end{tabular}

（受付1990年 2 月 5 日，揭載決定1990年 3 月 3 日）

Helium Pumping by a Cryosorption Pump with Condensed $\mathrm{SF}_{6}$

Gas Layer as a Sorbent in JT-60 NBI System

Kiyoshi SHIBANUMA**, Noboru AKINO**, Masayuki DAIRAKU**

Kazuharu HIRUTA**, Kazuhiro IIDA**, Katsumi KIKUCHI**

Syunsuke KUNIEDA**, Masaaki KURIYAMA**, Mamoru MATSUOKA**

Hiroki NOMOTO**, Yoshihiro OHARA**, Shouju OHUCHI, ${ }^{* *}$

Yutaka OHUCHI**, Masahiro SEKI**

Shigeru TANAKA** and Takuya TERAKADO**

(Japan Atomic Energy Research Institute, Naka Machi, Ibaraki)

(Received February 5, 1990, Accepted March 3, 1990)

\section{1.はじめに}

核融合実験炉では，D-T 燃焼により生じる He灰の 輸送, 排気が重要な研究課題の 1 つとなっている1).こ の $\mathrm{He}$ 灰の輸送，排気をより現実的に模擬するために は，プラズマ中心にピークをもった $\mathrm{He}$ の密度分布を形 成する必要がある。そのために，粒子入射加熱装置 （NBI）を用いてプラズマ中心へ $\mathrm{He}$ ビームの入射する ことが最も有効である.JT-60NBI を用いて He ビーム の入射を行らためには, $\mathrm{He}$ ガス排気用大容量真空排気 ポンプの開発が必要となり, その候補として, He ガス の吸着媒に $\mathrm{SF}_{6}$ ガス凝縮層を用いたクライオソープショ ンポンプが挙げられる2). この方式は, 既存の $\mathrm{H}_{2}$ ガス 排気用凝縮型クライオンポンプ内に $\mathrm{SF}_{6}$ ガス凝縮層形成 用の導入管を設置するだけで改造可能であり, $\mathrm{SF}_{6}$ ガス

* 平成元年10月26日 第30回真空に関する連合講演会で講演

** 日本原子研究所 那珂研究所 (茨城県那珂郡那珂町向山)
凝縮層を形成しない場合には，従来の $\mathrm{H}_{2}$ ガス用凝縮型 クライオポンプとしても使用できる.

ここでは, $\mathrm{He}$ ガス排気用 JT-60NBI 大容量クライオ ソープションポンプヘの改造と JT-60プラズマへの $\mathrm{He}$ ビーム入射試験を含めた $\mathrm{He}$ ガスの排気試験について報 告する.

2. He ガス排気用クライオソープションポ ンプへの改造

JT-60NBI は14基から構成され，そのらちの 1 基分の クライオポンプを Fig. 1 に示す. クライオポンプは 6 個のクライオポンプモジュールより成る $\mathrm{H}_{2}$ ガス排気用 のシェブロンを有する凝縮型ライオポンプである. NBI 真空容器内は差動排気を構成するために, 仕切り 板により仕切られた 3 つの部屋 $P_{1}, P_{2}, P_{3}$ に分割され, 各部屋にそれぞれ 2 個のクライオポンプモジュールが設 置されている. $\mathrm{H}_{2}$ ガスに対するクライオポンプ 1 基当 


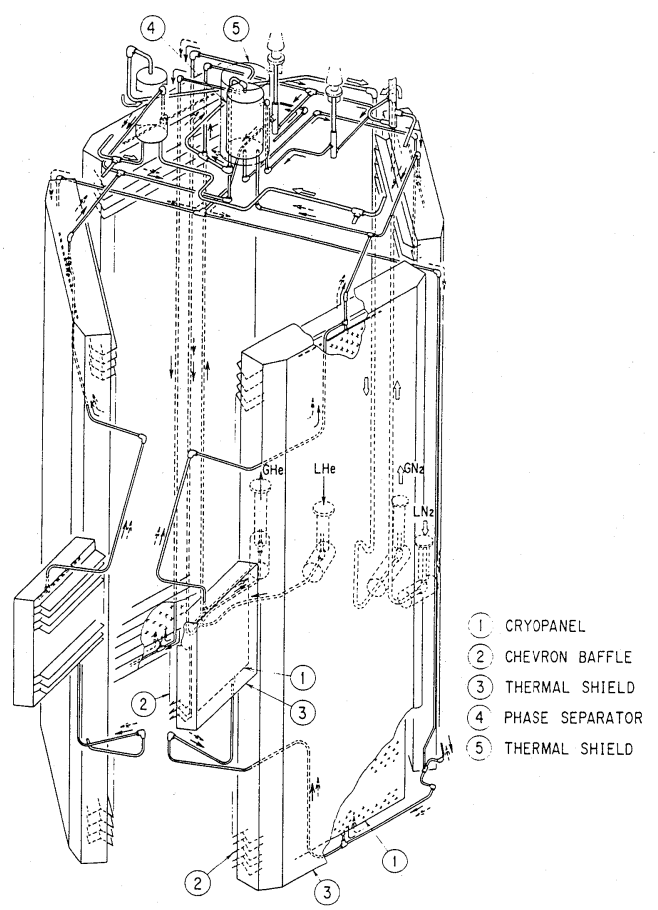

Fig. 1 Upper cryopump unit for the JT-60 NBI.

りの排気速度は $1370 \mathrm{~m}^{3} / \mathrm{s}$ であり, $\mathrm{H}_{2}$ ガス排気面となる クライオパネル面積は $15 \mathrm{~m}^{2}$ である3).

14基の NBI クライオポンプの 1 基（上ユニット）を $\mathrm{He}$ ガス排気用のクライオソープションポンプに改造し た.クライオパネル面に $\mathrm{SF}_{6}$ ガス凝縮層を形成させるた めに, Fig. 2 に示すよらに，ステンレス製 $\mathrm{SF}_{6}$ ガス導入 管をシェブロンとクライオパネル間に設置した。これら の導入管を, $P_{1}, P_{2}$ 室内の大型クライオポンプモジュー ルには左右対称に 2 本ずつ, $P_{3}$ 室内の小型クライオポ ンプモジュールにはほぼ中央に 1 本設置した。な抏, $\mathrm{SF}_{6}$ ガス導入時に，導入管内の $\mathrm{SF}_{6}$ ガスが放射冷却によ り $-50.8^{\circ} \mathrm{C}(2.21 \mathrm{~atm})$ の凝固点以下にならないように， 導入管自体を抵抗体として，直接通電することにより昇 温する対策を施した。

\section{3. 試験方法}

$\mathrm{He}$ ガス排気試験を行う際の試験手順を以下に示す.

(1)シェブロン, クライオパネルを液体窒素, 液体へリ ウムで冷却し，それぞれ77 K, $3.5 \mathrm{~K}$ とする. (2) $\mathrm{SF}_{6}$ ガ ス導入管を $20^{\circ} \mathrm{C}$ で昇温する. (3) $P_{1}, P_{2}, P_{3}$ の各部屋に それぞれ規定量の $\mathrm{SF}_{6}$ ガスを導入し，クライオパネル上 に $\mathrm{SF}_{6}$ ガス凝縮層を形成する. (4) $\mathrm{He}$ ガスを NBIイオ ン源より導入し, $\mathrm{He}$ ガスの排気実験を行ら.

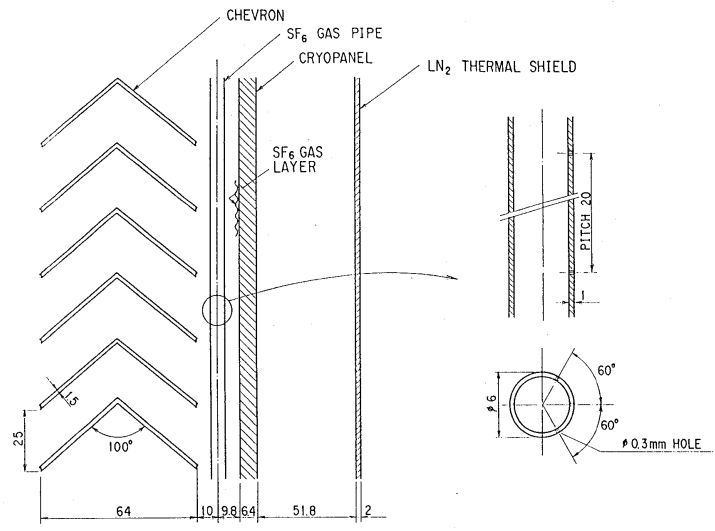

Fig. 2 Schematic diagram of cryopanel and $\mathrm{SF}_{6}$ gas introduction pipe.

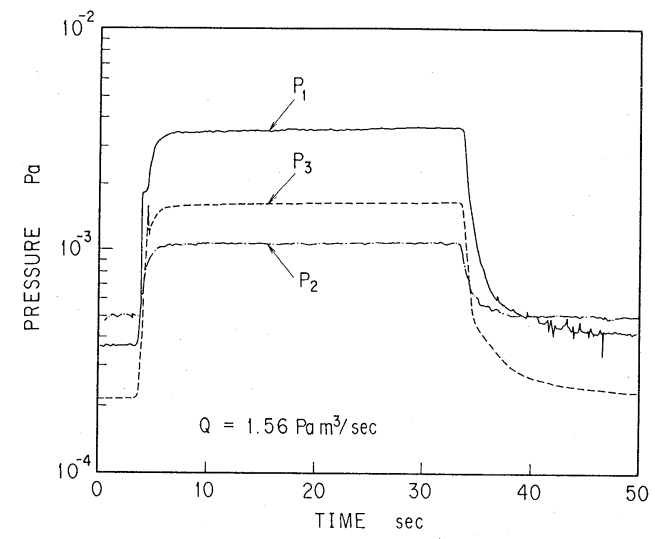

He GAS

Fig. 3 Pressure changes in the NBI chamber when helium gas was introduced through the ion sources.

クライオパネル面での $\mathrm{SF}_{6}$ ガス凝縮量は既報の小型ク ライオソープションポンプでの実験結果を参考に, 単位 面積当り約 $2500 \mathrm{Pam}^{3} / \mathrm{m}^{2}$ とした ${ }^{2)}$. その結果, $P_{1}, P_{2}$, $P_{3}$ の各部屋へそれぞれ40000 $\mathrm{Pam}^{3}, 40000 \mathrm{Pam}^{3}, 6000$ $\mathrm{Pam}^{3}$ の合計86000 $\mathrm{Pam}^{3} \mathrm{SF}_{6}$ ガスを導入した. $\mathrm{SF}_{6}$ ガス 及び $\mathrm{He}$ ガスの流量はサーマルマスフローメータにより 測定し, $\mathrm{He}$ ガス排気時における真空容器内の圧力は $\mathrm{He}$ ガスにより校正された B-A 型電離真空計により測定 した.

\section{4. 試 験 結 果}

\subsection{He ガスの排気特性試験}

JT-60プラズマへの $\mathrm{He}$ ビーム入射運転時における NBI イオン源よりの $\mathrm{He}$ ガス流量は1.5 2.0 $\mathrm{Pam}^{3} / \mathrm{s} て ゙$ 最大 10 秒間である．これを考慮して， $\mathrm{He}$ ガスを NBIイ 


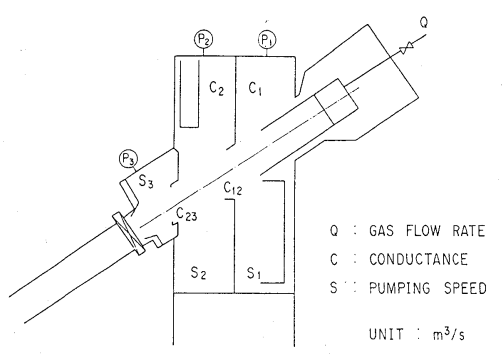

(a) Simplified calculation model

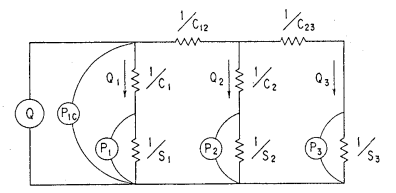

(b) Equivalent circuits

Fig. 4 Calculation model for the pumping speed estimation.

オン源より導入し, 真空容器内各部屋の圧力を測定し た.その結果をFig. 3 に示す. Fig. 3 より，30秒間 $\mathrm{He}$ ガスを導入しても圧力変動はほとんどなく, 非常に安定 な排気特性が確認でさた。さらに，2 $\mathrm{Pam}^{3} / \mathrm{s}$ までの $\mathrm{He}$ 流量に対する試験においても，排気速度はほぼ一定值を 持続することが確認された.

\section{$4.2 \mathrm{He}$ ガスに対する排気速度評価}

クライオソープションポンプの $\mathrm{He}$ ガスに対する排気 速度を評価するために, Fig. 4(a)のように真空容器を $P_{1}, P_{2}, P_{3}$ の 3 つの部屋に分割し, 各部屋間及び各部屋 内をコンダクタンスで連絡する構造に簡略化した。 Fig. 4(a)の具体的な計算モデルはFig. 4(b) に示す等価 回路であり, ガス流量 $Q$, 圧力 $P$, コンダクタンス $C$, 排気速度 $S$ 間の各関係は次式となり，これらの式により 排気速度が求められる。

$$
\begin{aligned}
& Q=Q_{1}+Q_{2}+Q_{3} \\
& P_{1 \mathrm{C}}=Q_{1} / C_{1}+P_{1} \\
& P_{1 \mathrm{C}}=\left(Q_{2}+Q_{3}\right) / C_{12}+Q_{2} / C_{2}+P_{2} \\
& P_{1 \mathrm{C}}=\left(Q_{2}+Q_{3}\right) / C_{12}+Q_{3} / C_{23}+P_{3} \\
& S_{1}=Q_{1} / P_{1} \\
& S_{2}=Q_{2} / P_{2} \\
& S_{3}=Q_{3} / P_{3}
\end{aligned}
$$

ここで，各ュンダクタンス $C_{1}, C_{2}, C_{12}, C_{23}$ は以下の方 法により求めた。 円形管, 矩形管にモデル化できる各部 屋間のコンダクタンス $C_{12}, C_{23}$ は, 従来のコンダクタン スに関する簡易式4)により求めた。簡単形状にモデル化 できない部屋内のコンダクタンス $C_{1}, C_{2}$ に関しては, $\mathrm{H}_{2}$ ガスに対するクライオポンプの排気速度が前もって

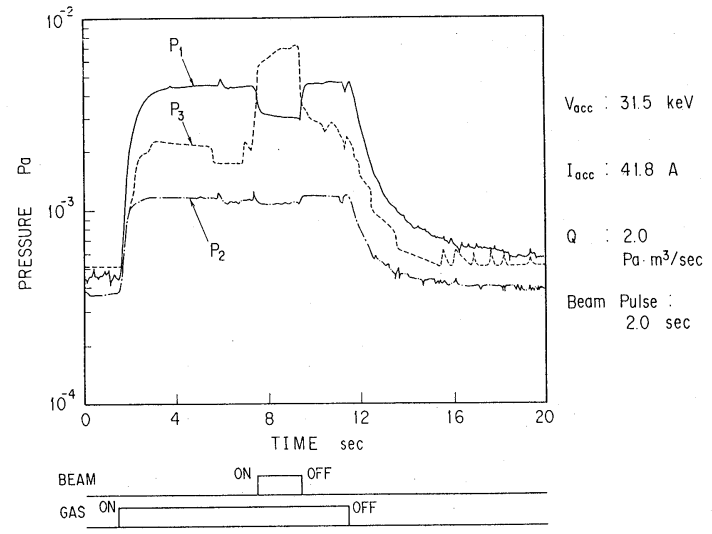

Fig. 5 Pressure changes in the NBI chamber when $31.5 \mathrm{keV}, 41.8 \mathrm{~A}$ and $2.0 \mathrm{~s}$ helium beam was extracted from the ion sources.

予測できるので5)，まず， $\mathrm{H}_{2}$ ガスに対するコンダクタ ンス $C_{1}, C_{2}$ を式(1) (6)より算出し, 次に $\mathrm{He}$ ガスへの分 子量換算を行らことにより, $\mathrm{He}$ ガスに対するコンダク タンス $C_{1}, C_{2}$ を求めた.

以上のコンダクタンスを用いて排気速度の計算を行っ た結果, He ガスに対する NBI クライオソープションポ ンプ 1 基当りの排気速度として $808 \mathrm{~m}^{3} / \mathrm{s}$ を得た.

\subsection{He ビーム入射時における He ガスの排気特性}

JT-60プラズマへの NBI による He ビーム入射試験時 に拈ける NBI 真空容器内各部屋の圧力変化を Fig. 5 に 示す. Fig. 5 において, $\mathrm{He}$ ビーム入射時における $P_{1}$ 室 の圧力低下は, He ビーム相当分のガスがビームダンプ 等の受熱機器に一担捕えられるビームポンピング効果に よるものである. また, $\mathrm{He}$ ビーム入射時の $P_{3}$ 室にお ける圧力上昇は， $P_{3}$ 室クライオポンプの異常ではなく, JT-60本体と NBI 真空容器間を連結するドリフト管内 で再電離した Heイオンビームが内壁に衝突し，その時 に壁から発生したアウトガスによるものである7). Fig. 5 の結果は, JT-60プラズマへのビーム入射が開始され て, 数ショット後の結果であり, ドリフト管内の $\mathrm{He}$ ビ ームによるエージング不足の状態のものである（ $\mathrm{H}_{2}$ ビ ームの場合, エージングに 50 ショット要した7)).

なお，今回の試験では， $\mathrm{SF}_{6}$ ガス導入量 $86000 \mathrm{Pam}^{3} に$ 対して, $\mathrm{He}$ ビーム入射に必要な $\mathrm{He}$ ガスを約 $2000 \mathrm{Pam}^{3}$ 導入したが，その間，クライオンープションポンプの排 気速度の低下はなく，まだ十分な $\mathrm{He}$ ガスの排気能力が 残されていることが明らかとなった。

\section{5. 結 論}

既存の $\mathrm{H}_{2}$ ガス排気用 JT-60NBI クライオポンプ 1 基 
を, $\mathrm{SF}_{6}$ ガス凝縮層を用いた $\mathrm{He}$ ガス排気用クライオン ープションポンプに改造し, JT-60プラズマへの長バル ス $\mathrm{He}$ ビーム入射実験を含めた $\mathrm{He}$ ガスの排気試験を行 った結果, 以下の結論を得た.

1）イオン源より $2 \mathrm{Pam}^{3} / \mathrm{s}$ をでの $\mathrm{He}$ ガス流量を $\mathrm{NBI}$ 真空容器内に導入した結果, $P_{1}, P_{2}, P_{3}$ の各部屋内 の排気速度は，注とんど変化せず一定值を示した。

2) NBI 1 基の $\mathrm{He}$ ガスに対する排気速度は約 $800 \mathrm{~m}^{3}$ /s となり， $\mathrm{He}$ ガスに対する世界最大の排気速度を得 た。

3） JT-60プラズマへの $\mathrm{He}$ ビーム入射試験において, $\mathrm{He}$ ガスの安定な排気が行われ，JT-60の実験目的であ る $\mathrm{He}$ 灰の挙動を調べるための実験が正常に行われた.

4) $\mathrm{SF}_{6}$ ガス凝縮層 $\left(\mathrm{SF}_{6}\right.$ ガス導入量 $\left.86000 \mathrm{Pam}^{3}\right)$ の
排気速度は, 約2000 $\mathrm{Pam}^{3}$ の $\mathrm{He}$ ガスを吸着した後でも 変化せず，まだ十分な排気能力が残されていることが確 められた。

\section{[文献]}

1) H. Nakamura et al., Fusion Technology 投稿中.

2）柴沼 清他：真空, .31（1988） 311.

3) K. Shibanuma et al.: 11th sympo. on Fusion Engineering (1985) 1273.

4）熊谷寛夫他編：真空の物理と応用（裳華房, 1970) 378.

5）柴田 猛順他：JAERI-M7869 (1978).

6) T. Shibata et al.: J. of Nuclear Materials, $128 \& 129$ (1984) 713.

7) M. Mizuno et al.: 12th sympo. on Fusion Engineering (1987) 281. 